\title{
Occurrence of antibodies against Neospora caninum in sows and factors associated with infection in commercial herds in two regions of the state of Santa Catarina, Brazil
}

\section{Ocorrência de anticorpos contra Neospora caninum em porcas e fatores associados à infecção em rebanhos comerciais de duas regiões de Santa Catarina, Brasil}

\author{
Marcio Orides da Silva ${ }^{1}$; Alessandra $\mathrm{Snak}^{2}$; Jessica Ceruti Reiter ${ }^{3}$; \\ Gilberto Serighelli Junior ${ }^{3}$; José Cristani ${ }^{4}$; Anderson Barbosa de Moura ${ }^{5 *}$
}

Highlights:

The importance of $N$. caninum infection in pigs has not been yet fully elucidated. High rates of $N$. caninum infection in pigs in Santa Catarina state were determined. Dogs, rodents, water supply type are associated factors for the infection.

\begin{abstract}
Neosporosis is a disease that affects ruminants, horses, swine, and wild animals, causing reproductive disorders and economic losses. The importance of the infection in pigs has not been fully elucidated. The objective of the present study was to verify the occurrence of antibodies against Neospora caninum and the possible factors associated with infection in swine herds from two regions of the state of Santa Catarina, Brazil. A total of 498 blood samples were collected from sows of western (five properties) and southern (four properties) regions of the state, and an epidemiological questionnaire was administered. Sera obtained from the blood were tested by indirect fluorescent antibody test (IFAT) (cutoff point 1:50) using tachyzoites of $N$. caninum $\mathrm{NC1}$ strain as antigen. Positive samples were two-fold serially diluted until maximum reactivity titer. The results were analyzed using Fisher and Chi-square tests to determine correlation between serology and associated factors. The overall prevalence was $18.9 \%$ (94/498) with titers of 50 (27), 100 (26), 200 (22), 400 (10), and 800 (9). Eighty of 256 samples (31.3\%) from the western region were positive, while 14 out of 242 samples $(5.8 \%)$ from the southern region were positive. A correlation $(\mathrm{p}<0.01)$ was observed among the seroprevalence and contact with dogs $(\mathrm{OR}=3.97$, IC 2.64-6.43), presence of rodents $(\mathrm{OR}=7.37$ IC 4.06-13.50), and water source $(\mathrm{OR}=$ 2.38 IC 1.44-3.91). The use of anti-bird nets was identified as a protective factor against infection (OR $=0.36$ IC $0.07-0.25$ ). These results demonstrate the high prevalence of antibodies against $N$. caninum in commercial swine herds in the state of Santa Catarina compared to that in other regions of Brazil.
\end{abstract}

Key words: IFAT. Neosporosis. Occurrence. Swine.

\footnotetext{
Médico Veterinário, M.e em Ciência Animal, Autônomo, Lages, SC, Brasil. E-mail: marcioorides@hotmail.com

2 Médica Veterinária, Discente de Doutorado em Ciência Animal, Universidade do Estado de Santa Catarina, UDESC, Lages, SC, Brasil. E-mail: alessandra.snak@hotmail.com

3 Discentes, Medicina Veterinária, UDESC, Bolsistas de Iniciação Científica, Lages, SC, Brasil. E-mail: ceruti.jessica@gmail. com; gilbertojr97@hotmail.com

4 Médico Veterinário, Dr. em Zootecnia, UDESC, Lages, SC, Brasil. E-mail: jose.cristani@udesc.br

5 Médico Veterinário, Dr. em Medicina Veterinária, UDESC, Lages, SC, Brasil. E-mail: anderson.moura@udesc.br

* Author for correspondence
} 


\begin{abstract}
Neosporose é uma doença que afeta ruminantes, equinos, suínos e animais selvagens, causando distúrbios reprodutivos e perdas econômicas. A importância da infecção em suínos não está totalmente elucidada. O objetivo do presente estudo foi verificar a ocorrência de anticorpos contra Neospora caninum e os possíveis fatores associados à infecção em rebanhos suínos de duas regiões do estado de Santa Catarina. Foram coletadas 498 amostras de sangue de porcas nas regiões oeste (cinco propriedades) e sul (quatro propriedades) do estado, e foi aplicado um questionário epidemiológico. Os soros obtidos foram avaliados pela Reação de Imunofluorescência Indireta (RIFI, 1:50) usando taquizoítos da cepa $\mathrm{NC} 1$ de $N$. caninum como antígeno. As amostras positivas foram analisadas em diluições seriadas de base dois até a titulação máxima reativa. Os resultados foram analisados por meio dos testes de Fisher e do qui-quadrado para determinar a correlação entre sorologia e fatores de risco. A prevalência geral foi de 18,9\% (94/498), com títulos de 50 (27), 100 (26), 200 (22), 400 (10) e 800 (9). Das 256 amostras da região oeste, $80(31,3 \%)$ foram positivas, enquanto $14(5,8 \%)$ das 242 amostras da região sul foram positivas. Observou-se correlação $(\mathrm{p}<0,01)$ entre soroprevalência e contato com cães $(\mathrm{OR}=3,97$; IC $2,64-6,43)$, presença de roedores ( $\mathrm{OR}=7,37 \mathrm{IC} 4,06-13,50)$ e fonte de água $(\mathrm{OR}=2,38 \mathrm{IC} 1,44-3,91)$. $\mathrm{O}$ uso de redes antipassáros foi identificado como fator de proteção contra a infecção $(\mathrm{OR}=0,36$ IC 0,07-0,25). Esses resultados demonstram a alta prevalência de anticorpos contra $N$. caninum em rebanhos suínos comerciais no estado de Santa Catarina em comparação com outras regiões do Brasil.

Palavras-chave: Neosporose. Ocorrência. RIFI. Suíno.
\end{abstract}

Neosporosis is caused by the protozoan Neospora caninum, which has been found naturally parasitizing cattle, goats, buffaloes, canids, foxes, swine, cervids, coyotes, and camels. Experimental infections have been described in swine, leporines, felines, canids (dog, fox, dingo, and coyote), and rodents (mice, rats, and gerbils) (Dubey, Schares, \& Ortega-Mora, 2007).

According to Waladjo, Chatagnon, Bailou and Diop (2009), the importance of neosporosis in pigs has not been clearly established. Its occurrence may be related to cases of abortion, stillbirths, return to estrus and other reproductive disorders, which reduce commercial production, thereby necessitating matrix substitution, even if clinically healthy. Studies about neosporosis in swine are scarce in Brazil and hence the present seroepidemiological survey was conducted.

This study was approved by the Ethical Commission on the Use of Animals of the Universidade do Estado de Santa Catarina (UDESC), under protocol n ${ }^{\circ} 6769310317$.

Between January and June 2017, 498 blood samples were collected from sows of commercial herds in nine farms located in two of the main producing regions of the state of Santa Catarina (west and south). Five farms in the western region and four farms in the southern region of the state were sampled totaling 256 and 242 samples, respectively. To determine the sample size, we used the methodology proposed by Sobestiansky, Wentz, Silveira and Sesti (1998) for a 5\% expected prevalence and a $95 \%$ confidence interval. Randomly selected samples were collected by venipuncture, the tubes capped, labeled, and transported to the Labratório de Parasitologia e Doenças Parasitárias, Centro de Ciências Agroveterinárias (CAV), Universidade do Estado de Santa Catarina (UDESC) where sera were obtained and stored at $-20^{\circ} \mathrm{C}$ for further processing by indirect fluorescent antibody test (IFAT).

An epidemiological questionnaire was administered during collection to evaluate contact with dogs, presence of rodents, water source, and presence of anti-bird nets on premises. Five of the properties sampled were located in the western region of the state of Santa Catarina and were numbered from 1 to $5 ; 53,52,51,51$, and 49 blood samples were respectively collected from these 
farms. Four other properties located in the southern region were numbered from 6 to $9 ; 62,60,55$, and 65 blood samples were respectively collected from these farms.

For IFAT, $N$. caninum strain $\mathrm{NC1}$ tachyzoites obtained by cell culture were used as antigen. IFAT was performed according to Conradetal.(1993)using a 1:200 PBS dilution of fluorescein isothiocyanatelabeled anti-swine IgG pH 7.2 (Sigma Chemical conjugate). Positive and negative control sera were included on each slide. Serum dilution 1:50 (cutoff) depicting complete fluorescence of $N$. caninum tachyzoites was considered positive (Lindsay et al., 1995). Titration of the positive samples was performed in two-fold serial dilutions until maximal reactivity dilution.

Serology results and data from the epidemiological questionnaire administered were tabulated and subjected to statistical analysis by Fisher's exact and chi-square tests $(\mathrm{P} \leq 0.05)$ ( $\mathrm{R}$ Core Team $\left.{ }^{\circledR}\right)$ to identify possible factors associated to the infection.

The overall prevalence of antibodies against $N$. caninum was $18.9 \%$ (94/498). Eighty of 256 samples from the western region were positive $(31.3 \%)$; of these samples, 16 were from herd (1), 15 from (2), 24 from (3), 16 from (4), and 9 from (5). Fourteen of the 242 samples analyzed from the southern region were positive (5.8\%); of these samples, 3 were from herd (6), 5 from (7), 4 from (8), and 2 from (9). The reciprocal of titers were distributed as follows: 50 (27 animals), 100 (26 animals), 200 (22 animals), 400 (10 animals) and 800 (9 animals).

The occurrence in the two regions varied from $5.8 \%$ to $31.3 \%$. Surveys conducted in Brazil and other parts of the world showed similar variable results, with lower or higher values than the ones reported in this study. For instance, a prevalence of $58.3 \%$ was found by Waladjo et al. (2009) in Senegal; other prevalence rates of $3.2 \%, 3.1 \%$, $18.8 \%, 3 \%$ and $8.8 \%$ were respectively reported by Feitosa et al. (2014), Azevedo et al. (2010), Bevins,
Blizzard, Bazan and Whitley (2013), Bartová and Sedlak (2011) and Helmick, Otter, Mcgarry and Buxton (2002). Damriyasa et al. (2004) found one positive sow out of 2041 sera analyzed.

In the present study $68.1 \%(64 / 94,95 \% \mathrm{CI}=$ 2.41-6.66) of the positive animals were from farms where dogs were present and in contact with the pigs and $65.1 \%$ of the negative animals were from farms where there were no dogs. Furthermore, the highest IgG antibody titers against $N$. caninum were observed in the presence of $\operatorname{dogs}(\mathrm{p}<0.01)$. On farms where pigs were in contact with dogs, the risk of infection was 3.97 times higher $(\mathrm{OR}=3.97)$ than on farms where pigs and dogs had no contact. Paré, Fecteau, Fortin and Marsolais (1998) studied 3059 dairy cows on 46 farms and found that the presence of dogs on the farm was a risk factor for protozoan infection. According to Dubey et al. (2007), dogs may expose animals to infection by defecating in food and water sources. Furthermore, it is advisable to adopt precautionary measures not only in the property but also in the region to avoid the contact of dogs with contaminated fetal tissues.

Farms where rodents were present or where rodent control programs were not established, showed a positive $(\mathrm{p}<0.01)$ correlation with seropositivity for $N$. caninum. Of the positive pigs, 31.3\% (80/94 $95 \% \mathrm{CI}=3.99-14.59$ ) had contact with rodents. In properties where there was no contact, only $5.8 \%$ of the animals were seropositive for $N$. caninum. The absence of rodent control programs or the presence of rodents in the properties sampled, proved to be a risk factor for $N$. caninum infection. In properties where pigs were in contact with rodents, the animals were 7.37 times more at risk $(\mathrm{OR}=7.38)$ of being seropositive for the agent. Dantas et al. (2013) analyzed blood serum samples from 476 dogs in the city of Natal (state of Rio Grande do Norte), using IFAT and found a prevalence of 11.5\% (55/476) for $N$. caninum. Huang, Yang, Watanabe, Liao and Ooi (2004) and Dubey et al. (2007) reported the presence of $N$. caninum DNA in mice and rat tissues; therefore these animals are an important source of 
infection and disease vectors. Analysis of factors associated with infection revealed that dogs that had contact with rats were 2.34 times more likely to be seropositive. The presence of rodents may represent a transmission pathway for carnivorous hosts (Dubey et al., 2007) and probably for pigs, which have omnivore eating habits.

The absence of anti-bird nets presented correlation $(\mathrm{p}<0.01)$ with serology. In properties where anti-bird nets were present, 5.8\% (95\% CI = $0.14-0.25)$ of the animals were considered positive whereas a seropositivity of $31.2 \%$ was observed among the sows where protective equipment was not available. The presence of anti-bird nets on the properties acted as a protective factor to infection by $N$. caninum $(\mathrm{OR}=0.14)$. Studies have shown that the presence of birds in dairy herds may be related to increased seroprevalence and to the occurrence of reproductive disorders associated with neosporosis, indicating that birds might be intermediate hosts and could thus serve as a transmission route for canids (Otranto et al., 2003). As pigs have omnivore alimentary habits, birds infected with the protozoan could act as a direct transmission route if ingested by the animals.

On farms where the water consumed by the animals was obtained from mines or unprotected sources that can be accessed by other animals, including wild ones, a prevalence of $30.8 \%$ and 2.38 times more risk of infection with $N$. caninum $(95 \% \mathrm{CI}=1.44-3.91, \mathrm{OR}=2.38)$ was determined. Farms that provided water to their animals only from artesian wells had a prevalence of $11.2 \%$ and 0.36 times less chance of seropositivity. Therefore, the type of water source may act as a protective factor against $N$. caninum infection $(95 \% \mathrm{CI}=$ $0.22-0.6, \mathrm{OR}=0.36$ ). In properties where the water supply was from the municipal sanitation system (CASAN), $18.36 \%$ of the animals were positive. Barling et al. (2001) sampled 76 farms in the state of Texas (USA) and determined a decrease in the risk of infection by N. caninum in properties where water sources and food were protected from wild animal access. Dubey et al. (2007) pointed out that the water consumed by the animals can be contaminated by oocysts and serve as a transmission route for animals.

A significant difference $(\mathrm{p}<0.01)$ was observed between the prevalences in the farms sampled. This difference could be related to the type of management adopted and its characteristics. The farms with the highest prevalence $(1,2,3,4$, and 5) had common characteristics such as contact of pigs with dogs, presence of rodents, absence of antibird nets, and unprotected water source. Barling et al. (2001) extensively sampled cattle farms in the USA and observed that more technified properties presented a lower seroprevalence for $N$. caninum due to the adopted management practices that did not allow the access of dogs from other properties, greater control of the sources of food and water, control of the origin of the animals, and more accurate reproductive management.

Table 1

Factors associated with Neospora caninum infections in commercial herds in Santa Catarina state (SC), Brazil

\begin{tabular}{cccc}
\hline Variable & OR & IC & P Value \\
\hline Dog contact & 3.97 & $2.41-6.66$ & $<0.0001$ \\
Rodent contact & 7.38 & $3.99-14.59$ & $<0.0001$ \\
Water source & 2.38 & $1.44-3.91$ & 0.0001239 \\
Anti-bird net & 0.14 & $0.07-0.25$ & $<0.0001$ \\
\hline
\end{tabular}


To our knowledge, this is the first study reporting the occurrence of antibodies against $N$. caninum in pigs in southern Brazil, and the results indicate that infection by this agent in sows is high and widespread in the studied region.

\section{References}

Azevedo, S. S., Pena, H. F. J., Alves, C. J., Guimarães, A. M., Fo., Oliveira, R. M., Maksimov, P.,... Gennari, S. M. (2010). Prevalence of anti Toxoplasma gondii and Neospora caninum antibodies in swine from northeastern Brasil. Revista Brasileira de Parasitologia Veterinária, 19(2), 80-84. doi: 10.4322/rbpv.01902002

Barling, K, S., McNeill, J. W., Paschal, J. C., McCollum III, F. T., Craig, T. M., Adams, L. G., \& Thompson, J. A. (2001). Ranch-management factors associated with antibody seropositivity for Neospora caninum in consignments of beef calves in Texas, USA. Preventive Veterinary Medicine, 52(1), 53-61. doi: 10.1016/S0167-5877(01)00233-1

Bartová, E., \& Sedlacl, K. (2011). Seroprevalence of Toxoplasma gondii and Neospora caninum in slaughtered pigs in the Czech Republic. Parasitology, 138(11), 1369-1371. doi: 10.1017/ S003118201100104

Bevins, S., Blizzard, E., Bazan, L., \& Whitley, P. (2013). Neospora caninum exposure in overlapping population of coiyotes (Canis latrans) and feral swines (Sus scrofa). Journal of Wildlife Diseases, 49(4), 1028-1032. doi: 10.7589/2013-02-034

Conrad, P. A., Sverlow, K., Anderson, M., Rowe, J., Bom Durant, R., Tuter, G.,... Ardans, A. (1993). Detection of serum antibody responses in cattle with natural or experimental Neospora spp. infections. Journal of Veterinary Diagnostic Investigation, 5(4), 572-578. doi: $10.1177 / 104063879300500412$

Damriyasa, I. M., Bauer, C., Edelhofer, R. Failing, K., Lind, P., Petersen, E.,... Zahner, H. (2004) Cross-sectional survey in pig breeding farms in Hesse, Germany: seroprevalence and risk factors of infections with Toxoplasma gondii, Sarcocystis spp. and Neospora caninum in sows. Veterinary Parasitology, 126(3), 271-286. doi: 10.1177/104063879300500412

Dantas, S. B. A., Fernander, A. R. F., Souza, O. B., Neto, Mota, A., Alves, C. J., \& Azevedo, S. (2013). Ocorrência e fatores de risco associados a infecções por $T$. gondii e N.caninum em cães do município de Natal, estado de Rio Grande do Norte, nordeste
Brasil. Ciência Rural, 43(11), 242-248. doi: 10.1590/ S0103-84782013001100020

Dubey, J. P., Schares, G., \& Ortega-Mora, L. M. (2007). Epidemiology and control of neosporosis and Neospora caninum. Clinical Microbiology Reviews, 20(20), 323-367. doi: 10.1128/CMR.00031-06

Feitosa, T. F., Vilela, V. L. R., Melo, L. R. B., Almeida, J. L., Neto, Souto, L. R. B., Morais, D. F.,... Pena, S. S. J. (2014). Toxoplasma gondii and Neospora caninum in slaughtered pigs from northeast Brazil. Veterinary Parasitology, 202(3), 305-309. doi: 10.1016/j. vetpar.2014.03.015

Helmick, B., Otter, J., Mcgarry, D., \& Buxton, D. (2002). Serological investigation of aborted sheep and pigs for infection by Neospora caninum. Research in Veterinary Science, 73(2), 187-189. doi: 10.1016/ S0034-5288(02)00093-0

Huang, C. C., Yang, C. H., Watanabe, Y., Liao, Y. K., \& Ooi, H. K. (2004). Finding of Neospora caninum in the wild brownrat (Rattus norvegicus). Veterinary Research, 35(3), 283-290. doi: 10.1051/ vetres:2004010

Lindsay, D. S., Rippey, N. S., Powe, T. A., Sartin, E. A., Dubey, J. P., \& Blagburn, B. L. (1995). Abortions, fetal death, and stillbirths in pregnant pygmy goats inoculated witch tachyzoites of Neospora caninum. American Journal of Veterinary Research, 56(9), 1176-1180.

Otranto, D. L., Llazari, A., Traversa, D., Regalbono, F., Badan, M., \& Capelli, G., (2003). Seroprevalence and associated risk factors of neosporosis in beef and dairy cattle in Italy. Veterinary Parasitology, 118(1), 7-18. doi: 0.1016/j.vetpar.2003.10.008

Paré, J., Fecteau, G., Fortin, M., \& Marsolais, G., (1998). Seroepidemiologic study of Neospora caninum in dairy herds. Journal of the American Veterinary Medical Association, 213(11), 1595-1598.

R Development Core Team. R: A language and environment for statistical computing. R Foundation for Statistical Computing, Vienna: 2009. Recovered form http://www. R-project.org

Sobestiansky, J., Wentz, I., Silveira, P. R., \& Sesti, L. A. C. (1998). Suinocultura Intensiva: produção, manejo e saúde do rebanho. Brasília: EMBRAPA.

Waladjo, A. R., Chatagnon, S. N., Bakou, H., \& Diop, P. E. H. (2009). Neospora caninum antibodies and its consequences for reproductive characteristics in wandering sows from Senegal West África. Asian Journal of Animal and Veterinary Advances, 4(5), 263-266. doi: 10.3923/ajava.2009.263.266 
